\title{
Do the professionals of social and health care have enough IT know- how required for the leap toward the digital era?
}

According to an OECD study $49 \%$ of Finnish people aged 16-65 have basic IT skills or then no IT skills at all. Indeed, in the younger age group of 25-35 the skills are significantly better than in the group of 50-65 year-olds. According to the Kuluttajabarometri survey $89.8 \%$ of households had internet access in August 2016. However writing an email or browsing the web are not adequate IT skills when it comes to business.

The goal of the national Sote-tieto hyötykäyttöön -strategia 2020 is to support the structural reform of the social and health care services as well as citizens' activity in the maintenance their own wellbeing. The premise for the structural reform is that information management and electronic services support the new structures and operating models.

Electronic services in social and health care include all the services that use information and communication technology such as consultation services between professionals, self-help services intended for customers, appointment booking services and the national health information system services (electronic prescription, Pharmaceutical Database, My Kanta pages, and Patient Data Repository). The goal of using electronic services is equal, effective and customer oriented access to social and health care services.

Citizens should be able to use these electronic services and with the help of the services evaluate and promote their wellbeing, prevent illnesses and communicate with professionals. Yet traditional services cannot be completely replaced with electronic ones. Professionals in social and health care must be prepared to use different client or patient information systems and the new electronic services as well as to support clients or patients in using the services. Nor may data security issues be forgotten.

Professionals in social and health care must have many skills, both vocational and technical, including special skills in information management for those involved in developing innovations. In addition to IT skills, problem solving, leadership, communication and team work skills are also needed.

Professionals should be able to accurately record data on the treatment or services provided to clients/ patients so that the information gathered can be processed into knowledge. This will help not only the service system but also the citizens in promoting health and wellbeing. The focus of development work should shift from gathering and transferring data to making better use of it. The data gathered in itself will not change functions: leadership and the ability to read and interpret numbers are also required in order to make changes.

Most graduating students now possess basic IT skills. Basic, advanced and supplementary education and training in social and health care should include studies in information management, information system security and using information systems. Yet most of today's professionals have undergone their basic education at a time before digitalization. Employees should be able to maintain their current skills and learn new skills that meet the demands of the changing world. Employers need to meet the challenge of motivating their employees to educate themselves but also organize whatever supplementary education is required.

The know-how related articles in this number describe the demands for expertise and special qualifications of nurses and doctors to be accomplished by on-the-job learning or via supplementary education. The professionals who already possess these special qualifications are only a small portion of the personnel currently in social and health care. How can it be guaranteed in the future that all the professionals will have the required know-how?

\section{Kristiina Häyrinen \\ Editor-in-Charge}

